\title{
The Relationship between Preservice Elementary Mathematics Teachers' Beliefs and Metacognitive Awareness
}

\author{
Lynn Cecilia Hart ${ }^{1}$, Dilek Sezgin Memnun ${ }^{2}$ \\ ${ }^{1}$ College of Education, Georgia State University, GSU, USA \\ ${ }^{2}$ Faculty of Education, Uludag University, Turkey \\ Correspondence: Dilek Sezgin Memnun, Uludag University, Faculty of Education, Gorukle, Nilufer, Bursa, Turkey
}

Received: May 25, 2015 Accepted: June 15, $2015 \quad$ Online Published: July 1, 2015

doi:10.11114/jets.v3i5.840 URL: http://dx.doi.org/10.11114/jets.v3i5.840

\begin{abstract}
The purpose of this study was to examine the metacognitive awareness and the beliefs about mathematics teaching and learning of preservice elementary mathematics teachers and to explore the relationship between the two. The Metacognitive Awareness Instrument (MAI) and the Mathematics Beliefs Instrument (MBI) were implemented with 118 elementary mathematics preservice teachers studying in a large urban university in northwestern Turkey during the 2011-2012 academic year. Statistical analysis results revealed that elementary mathematics preservice teachers' knowledge about cognition and regulation of cognition specific domains of metacognition did predict together their beliefs about mathematics teaching and learning.
\end{abstract}

Keywords: beliefs about mathematics, metacognition, metacognitive awareness, preservice teachers

\section{Introduction}

\subsection{The Problem}

Metacognition is a critical component of effective learning. It allows students to be aware of and regulate their thinking, control their decision-making and control their learning (Kuiper, 2002; Lucangeli, \& Cornoldi, 1997; Schraw \& Graham, 1997). Students who have high metacognitive awareness levels are aware of their performances and perform better in learning (Swanson, 1990). Those students plan their study, sequence, and obtain information about their cognitive processes. Metacognition increases their academic success (Cardelle-Elawar, 1992; Schraw \& Sperling-Dennison, 1994). It is important, therefore, to examine metacognitive awareness and explore how to develop awareness. Additionally, affective variables such as beliefs, excitement and enthusiasm also affect students' learning (McLeod, 1992). In this study we examine the metacognitive awareness and beliefs about mathematics teaching and learning of preservice elementary mathematics teachers to explore the relationship.

\subsection{Importance of the Problem}

Beliefs are the personal values and judgments that are formed through past experiences of individuals (Raymond, 1997). There is a critical interaction between beliefs, attitudes, and behavior (Taskin-Can, Canturk-Gunhan, \& Ongel-Erdal, 2005). An individual's beliefs can form the base from which positive attitudes and behaviors emerge and these behaviors are important in the learning process (Kloosterman \& Stage, 1992). Accordingly, mathematical beliefs can also have a negative influence on learning and the success of individuals (Kloosterman, 1991; Kloosterman \& Cougan, 1994; Thompson, 1984). Because of the importance of developing positive mathematical beliefs during school life (Raymond, 1997), beliefs are emphasized in different curriculum standards from various nations (National Council of Teachers of Mathematics, 2000 [U.S.]; Ministry of Education, 2008, [Turkey]). Finally, teachers play an important role in the development of their students' mathematical beliefs (Carter \& Norwood, 1997).

In general terms metacognition is thought of as thinking about thinking (Akin, Abaci, \& Cetin, 2007; Blakey \& Spence, 1990; Livingston, 1997). Cross and Paris (1988) define metacognition as "the knowledge and control children have over their own thinking and learning activities" (p.131). Martinez (2006) defines metacognition as "the monitoring and control of thought" (p. 696). 
While exact definitions vary slightly, several researchers (Schraw \& Sperling-Dennison, 1994; Schraw, Crippen, \& Hartley, 2006; Schraw \& Moshman, 1995; Pintrich, 2002) agree that metacognition includes two domains: Knowledge about cognition and regulation of cognition. Knowledge about cognition is the acquired knowledge about ones cognitive processes, including the beliefs related to cognitive aims and personal skills, and the selection and organization of an appropriate strategy or strategies used in the cognitive process. This knowledge helps individuals understand which strategies are efficient and effective for problem solving in mathematics education (Akin, Abaci, \& Cetin, 2007; Artzt \& Armour-Thomas, 1992; Jacobs \& Paris, 1987; Livingston, 1997; Pintrich, 2002; Schraw, Crippen, \& Hartley, 2006; Sperling et al., 2004). Regulation of cognition relates to selection of appropriate strategies, organization of cognitive resources, identification of mistakes during a performance, evaluation of the effectiveness of learning strategies, and rejection of strategies that are not appropriate (Schraw \& Moshman, 1995; Schraw \& Sperling-Dennison, 1994; Zimmerman, 1989). This domain involves the self-awareness of performance as a learner tackles a problem, their analysis of whether their performance is effective or not, predictions about their performances in the future, and the learners' evaluation of the effectiveness of their own learning and regulation processes (Everson \& Tobias, 1998; Nietfeld, Cao, \& Osborne, 2005; Schraw \& Moshman, 1995; Zimmerman \& Paulsen, 1995). In brief, metacognitive awareness allows individuals to become aware of and regulate their thinking and decision-making, makes it easier for individuals to control their learning, and supports reflective thought (Kuiper, 2002; Schraw \& Graham, 1997).

Individuals who have a high level of metacognitive awareness are aware of their performances and typically perform better in mathematical problem solving (Swanson, 1990). These individuals plan their work, sequence and obtain information about their cognitive processes, and therefore increase their performance and success (Schraw \& Sperling-Dennison, 1994). Because of that, metacognitive awareness supports learning and affects success in a positive way (Cardelle-Elawar, 1992; Kuiper, 2002; Lin, 2001). Additionally, teachers can play an important role in the development of their students' metacognitive abilities and awareness. Teacher can increase students' mindfulness about the importance of metacognitive awareness and provide opportunities to make metacognition transparent during problem solving (Butler \& Winne, 1995; Thomas \& McRobbie, 2001). Finally, preservice teachers need to develop their own metacognitive awareness if they are to nurture that in their future students.

\subsection{Related Literature}

\subsubsection{Mathematical Beliefs}

The beliefs of elementary preservice teachers about mathematics have been examined in several studies of university teacher education programs. Aksu (2008) explored the differences in the self-efficacy beliefs of primary preservice teachers with respect to several variables. He found that while the teachers generally had high self-efficacy beliefs regarding mathematics, there were no significant differences with respect to gender, graduation type or the departments of study. In another study, Philipp et al. (2007) looked at the content knowledge and beliefs of preservice primary school teachers after engaging in various interventions. They indicated that preservice teachers developed more sophisticated beliefs about mathematics, teaching, and learning when they were provided with opportunities to learn about children's mathematical thinking while they were learning the mathematics. Several studies (Author, 2002; Swars et al., 2007; Szydlik, Szydlik, \& Benson, 2003; Wilkins \& Brand, 2004), examined the impact of a change in the culture of mathematics content/methods courses that were designed to foster autonomous mathematical behaviors. They evaluated the effectiveness of these courses on preservice teachers' beliefs about teaching and learning. Two of the studies (Author, 2002; Wilkins \& Brand, 2004) found a positive relationship between participating in a well organized mathematics methods courses and change in preservice teachers' beliefs. Swars et al. (2007) found that the preservice teachers' pedagogical beliefs became more cognitively oriented and teaching efficacy beliefs for mathematics were strengthened. They also found a positive relationship between pedagogical and teaching efficacy beliefs. Finally, Szydlik, Szydlik and Benson (2003) attributed changes in teachers' beliefs to specific classroom social norms and socio-mathematical norms that included a broadening of the acceptable methods of solving problems, a focused explanation and argument, and the opportunity to generate mathematics as a classroom community. In sum, beliefs play an important role in behavior and learning. Teachers play an important role in developing beliefs in students, and teachers' beliefs can be changed to be more cognitively aligned to support student learning.

\subsubsection{Metacognitive Awareness}

Several studies have investigated the metacognitive knowledge and awareness of elementary preservice teachers. Metallidou (2009) found that preservice teachers with strong metacognitive knowledge had an increased incidence of using specific problem-solving strategies and producing appropriate strategies. Okcuoglu and Kahyaoglu (2007) found that the organization and inspection strategies usage of the teachers in the study were better than their planning and evaluation strategies. Ozsoy and Gunindi (2011) analyzed preservice teachers' metacognitive awareness and found that 
the preservice elementary teachers in the study had mid-level awareness. In other studies (Author, 2012; Yavuz \& Memis, 2010), researchers investigated self-efficacy perceptions, measured the metacognitive awareness levels of elementary mathematics preservice teachers, and explored the differentiation of awareness levels according to course grades. Author (2012) indicated that most of the elementary mathematics teacher trainees had relatively high levels of awareness and there was a low level, positive relationship between their metacognitive awareness levels and course grades. Yavuz and Memis (2010) found that the preservice teachers in their study had sufficient self-efficacy with metacognitive awareness being rather high.

\subsubsection{Metacognition and Beliefs}

Limited studies have looked at metacognition and beliefs together (Bendixen \& Hartley, 2003; Guven \& Belet, 2010). In both of these studies, the relationship of preservice elementary teachers' metacognition and beliefs were examined, together with student achievement. Bendixen and Hartley (2003) examined the relationship between epistemological beliefs, metacognition, and student achievement in a hypermedia learning environment. They indicated that reading comprehension, grade point average and fixed ability, omniscient authority and quick learning components related to epistemological beliefs significantly predicted posttest performance of preservice elementary teachers. Guven and Belet (2010) looked at determining opinions of primary school teacher trainees' metacognition and epistemological beliefs. They found that teacher trainees who believed learning as effort rather than ability were more metacognitively aware and monitored their learning. Neither of the studies explores the potential relationship between beliefs and metacognitive awareness.

\subsection{Research Questions}

The present study explores the relationship between beliefs about teaching and learning mathematics and the metacognitive awareness of elementary mathematics preservice teachers. Therefore, we raise the following research questions:

1. Is there a significant relationship between beliefs about mathematics teaching and learning and metacognitive awareness, specifically the subdomains of knowledge about cognition and regulation of cognition?

2. What is the ability of a model containing knowledge about cognition and regulation of cognition domains related to metacognitive awareness in predicting elementary mathematics preservice teachers' beliefs about mathematics teaching and learning?

\section{Methods}

This section includes sets of data and statistical analyses about the research model, the students who participated in the study, and the measurement tools.

\subsection{Participants}

The participants of this study consisted of 118 elementary mathematics preservice teachers enrolled in a teacher preparation program in a large urban university in the northwestern Turkey. The Faculty of Education grants several 4-year degrees in teacher preparation areas. The program in which the participants were enrolled was the undergraduate program in elementary mathematics teaching during 2011-2012 academic year.

The participants had demographics that were typical of this program; they were preservice teachers in college $(\mathrm{N}=118$ : 20-22 years old [108]; females [98]). Ethnicity was not collected.

\subsection{Instruments}

Two instruments were used to measure participants' metacognitive awareness and beliefs about mathematics teaching and learning: the Metacognitive Awareness Inventory- MAI (1994) and the Mathematics Beliefs Instrument-MBI (2002). The psychometric properties of the MAI and MBI instruments are presented in Table 1.

Table 1. Instrumentations used in the study

\begin{tabular}{lll}
\hline Instruments & Descriptors & Reliability \\
\hline MAI & Knowledge about Cognition average scores range from 2.47 to 4.94 & Cronbach alpha $=.88$ \\
& Regulation of Cognition average scores range from 2.37 to 4.66 & Cronbach alpha $=.93$ \\
& Total MAI average scores range from 2.52 to 4.75 & Cronbach alpha $=.92$ \\
\multirow{2}{*}{ MBI } & Total MBI average scores range from 2.07 to 3.57 & Cronbach alpha $=.71$ \\
\hline
\end{tabular}


The MBI was adapted from previous work of Schoenfeld (1989), and Zollman and Mason (1992) by the Author (2002). This instrument is a 30-item instrument in which all of the items are presented on a 4-point Likert scale. This instrument measures the consistency of individuals' beliefs about mathematics teaching and learning with the NCTM Curriculum and Evaluation Standards, their beliefs about teaching and learning mathematics within and outside the school setting, and individuals' perceptions of their effectiveness as a mathematics teacher and learner. Written as a 4-point Likert scale, the highest point value that could be obtained for this instrument is 120 and the lowest point is 30 . Eight language experts translated the MBI into Turkish. Three mathematics educators organized the translated items. Each item was confirmed and used in this research. Cronbach Alpha coefficient for the MBI was calculated as . 71 for the data. Since the value of the instrument was above .70 we determined that the instrument was reliable (Buyukozturk, 2010: 171).

The MAI was developed by Schraw and Sperling-Dennison (1994) and transcribed into Turkish by Akin, Abaci, \& Cetin (2007). This inventory is a 52-item scale in which all of the items are presented on a 5-point Likert scale. It does not contain negative items, and constitutes eight sub-domains, grouped under two domains: knowledge about cognition and regulation of cognition. (Artzt \& Armour-Thomas, 1992, Schraw \& Sperling-Dennison, 1994). Knowledge about cognition domain includes 17 items, and regulation of cognition domain includes 35 items. Written as a 5-point Likert scale, the highest point value that could be obtained for this instrument is 260 and the lowest point is 52. Each item for the Turkish version was confirmed and used in this research. The internal consistency reliability coefficient was .95 for the Turkish version of the inventory (Akin, Abaci \& Cetin, 2007). Cronbach Alpha coefficient for this instrument was calculated as .92 for the data obtained from this study. They were calculated as 0.88 (knowledge about cognition) and 0.93 (regulation of cognition) for the two domains.

\subsection{Data Collection and Analysis}

The MAI and the MBI were administered to preservice teachers while attending geometry, calculus, or statistics courses for preservice teachers in the spring semester of the 2011-2012 academic year. Preservice teachers who volunteered to participate in this study completed the MAI and the MBI within 40 minutes. Each participant coded the surveys responses independently.

Responses for MAI items were coded as $1=$ never to $5=$ always for all items and total points were calculated for knowledge about cognition and regulation of cognition domains separately. Additionally, MBI items were coded as $1=$ strongly disagree to $4=$ strongly agree for positive items and reverse coded for negative items, and total points were calculated. The awareness levels or belief average scores of preservice teachers were found by dividing the total points obtained on the instrument by the number of items in the instrument. Higher average scores indicate stronger, positive mathematical beliefs more consistent with the NCTM Standards or higher levels of metacognitive awareness.

Pearson correlations were calculated using the metacognitive awareness and mathematical belief average scores to show the relationship between beliefs about mathematics teaching and learning and each of the domains related to metacognitive awareness. Correlations were deemed significant at the a priori alpha level of .01. Multiple linear regression analysis was used to investigate whether or not average scores for knowledge about cognition and regulation of cognition domains related to the metacognitive awareness can predict preservice teachers' beliefs about mathematics teaching and learning average scores. The data were analyzed using the SPSS 14.0 program.

\section{Results}

Correlation analysis results for beliefs about mathematics teaching and learning (contains beliefs with the NCTM Curriculum and Evaluation Standards within and outside the school setting, and perceptions of the effectiveness as a teacher and learner), metacognitive awareness and its domains (knowledge about cognition and regulation of cognition) average scores are given in Table 2.

Table 2. Correlations between predictor variables and criterion variable (MBI)

\begin{tabular}{lc}
\hline & Beliefs about mathematics teaching and learning \\
\hline Knowledge about cognition & $.296^{*}$ \\
Regulation of cognition & .025 \\
\hline${ }^{*}<<.01$ &
\end{tabular}

Elementary mathematics preservice teachers' knowledge about cognition average scores had a significant, low-level positive correlation with MBI scores $(\mathrm{r}=.296, \mathrm{p}=.001, \mathrm{n}=118)$, while regulation of cognition average scores did not correlate with preservice teachers' MBI scores $(\mathrm{r}=.025, \mathrm{p}=.784, \mathrm{n}=118)$.

We ran regression analysis in order to determine whether or not the two domain average scores related to the 
metacognitive awareness (knowledge about cognition, regulation of cognition) can predict preservice teachers' beliefs about mathematics teaching and learning average scores. The results are included in Table 3.

Table 3. Model summary of multiple regression analysis

\begin{tabular}{lccc}
\hline & \multicolumn{3}{c}{ Beliefs } \\
\cline { 2 - 4 } Metacognitive awareness & $\mathrm{B}$ & $\beta$ & $\mathrm{p}$ \\
\hline Knowledge and cognition & 0.342 & 0.597 & .000 \\
Regulation and cognition & -0.221 & -0.412 & .001 \\
$\mathrm{R}=0.408$ & $\mathrm{R}^{2}=0.167$ & $\mathrm{~F}(2,115)=11.496$ & $\mathrm{p}=.000$ \\
\hline * $\mathrm{p}<.01$ & &
\end{tabular}

Elementary mathematics preservice teachers' knowledge about cognition and regulation of cognition domain average scores did predict together their beliefs about mathematics teaching and learning scores $[\mathrm{p}=.000, \mathrm{df}=2, \mathrm{~F}(2,115)=$ 11.496]. However, this result may not generalize beyond the population under study, as evidenced by the low $\mathrm{R}$ square value $\left(R^{2}=0.167\right)$ reported in this research. The $R$ square value reveals that the two domains related to metacognitive awareness (knowledge about cognition and regulation of cognition) together accurately predict $16.7 \%$ of the beliefs about mathematics teaching and learning of elementary mathematics preservice teachers. Besides, the analysis results showed that both of the domains are important predictors of beliefs about mathematics teaching and learning. The two predictor variables both showed significant contributions to the regression model: knowledge about cognition $(\mathrm{B}=0.342$, $\beta=0.597, p=.000)$, and regulation of cognition $(B=-0.221, \beta=-0.412, p=.001)$. Regulation of cognition variable provided a negative contribution to this regression model while the knowledge about cognition variable provided a positive contribution.

\section{Conclusions and Discussion}

The cognitive and affective experiences of preservice teachers are vital in mathematics education (Bingham-Brown, 2012). Metacognitive awareness and mathematical beliefs are developed during those experiences, and are critically important for mathematics education (Kloosterman, 1991; Kloosterman \& Cougan, 1994; Lucangeli, \& Cornoldi, 1997; Schraw \& Sperling-Dennison, 1994). Metacognitive awareness increases students' ability to organize and control their learning process, and therefore increases success in learning (Cardelle-Elawar, 1992; Kuiper, 2002; Schraw \& Sperling-Dennison, 1994). Similarly, mathematical beliefs are critical in determining what and how students interpret and benefit from the learning experience (Kloosterman, 1991; Kloosterman \& Stage, 1992). Additionally, teachers are important for the development of their students' mathematical beliefs and metacognitive awareness (Carter \& Norwood, 1997). Because of this critical relationship, we assessed the beliefs about mathematics teaching and learning and the metacognitive awareness of preservice elementary teachers and we explored the relationship between the two.

In the present study, elementary mathematics preservice teachers' beliefs about mathematics teaching and learning correlated positively with the knowledge about cognition domain of metacognitive awareness. The regression analysis results showed that knowledge about cognition was a significant predictor of their beliefs about mathematics teaching and learning. These findings have optimistic implications, particularly in the context of the learning process in mathematics education since knowledge about cognition domain is related to the knowledge about cognitive processes and management of cognition (Cross \& Paris, 1988; Livingston, 1997). Knowledge about cognition is related to knowledge about which strategy learners will use and how it will be used for cognitive work (Jacobs \& Paris, 1987; Pintrich, 2002; Sperling et al., 2004). We know that mathematical beliefs affect mathematics learning and success (Kloosterman \& Cougan, 1994; Thompson, 1984). In the light of this finding, it is probable that elementary preservice teachers with high knowledge of cognition who can control their cognitive processes, and choose an appropriate strategy or strategies may have more positive beliefs. Differently, preservice teachers' beliefs about mathematics teaching and learning did not have a significant correlation with their regulation of cognition variable while this variable is a significant predictor of their mathematical beliefs. As previously noted, this variable provided a negative contribution to the regression model. We conclude, at least for these participants, that metacognitive awareness does affect mathematical beliefs of elementary mathematics preservice teachers.

\section{Implications}

These findings suggest that preservice teachers who have a high level of metacognitive awareness may (1) have beliefs about mathematics teaching and learning sufficiently that are more consistent with reform perspectives in mathematics education, (2) be more successful in providing experiences for their students that develop positive beliefs about mathematics, and (3) be able to support their students' academic success. These preservice teachers will most likely use their metacognitive abilities more effectively in their practice (Ekiz \& Yigit, 2007; Marshall, 2003). Having knowledge 
about metacognitive processes and using these processes in effective and productive ways increases the metacognitive awareness levels of individuals (Marshall, 2003). That suggests that future research should be initially focused on not only the development of metacognitive awareness but also different variables such as grades in school. In addition, different activities could be suggested to develop and support knowledge, skills and awareness of metacognition in future studies.

Having a high level of metacognitive awareness is a significant aspect of being a highly effective teacher in mathematics education. Given that metacognition is related to the mathematical beliefs of elementary mathematics preservice teachers, enhancing teachers metacognitive awareness is important in developing appropriate, productive beliefs about mathematics teaching and learning. Additionally, positive mathematical beliefs are needed to be a strong mathematics teacher and affect mathematics success of their students (Kloosterman, 1991; Kloosterman \& Stage, 1992; Thompson, 1984). Therefore, the development of increased metacognitive awareness should go hand in hand with developing positive mathematical beliefs. Preservice elementary teachers' metacognition and beliefs were examined together in very few studies (Bendixen \& Hartley, 2003; Guven \& Belet, 2010). Because of that, future studies could focus on the development of productive mathematical beliefs of preservice teachers, especially elementary preservice teachers depending on the increased metacognitive awareness. University education programs need to focus on the development of preservice teachers' metacognitive awareness levels with respect to their effectiveness as a mathematics teacher or learner.

\section{References}

Akin, A., Abaci, R., \& Cetin, B. (2007). The validity and reliability of the Turkish version of the metacognitive awareness inventory. Educational Sciences: Theory \& Practice, 7(2), 671-678.

Aksu, H. H. (2008). Preservice teachers' self-efficacy beliefs towards mathematics teaching. Abant İzet Baysal Üniversitesi Eğitim Fakültesi Dergisi, 8(2), 161-170.

Artzt, A. F., \& Armour-Thomas, E. (1992). Development of a cognitive-metacognitive framework for protocol analysis of mathematical problem solving in small groups. Cognition and Instruction, 9(2), 137-175. http://dx.doi.org/10.1207/s1532690xci0902_3

Bendixen, L. D., \& Hartley, K. (2003). Successful learning with hypermedia: The role of epistemological beliefs and metacognitive awareness. Journal of Educational Computing Research, 28(1), 15-30. http://dx.doi.org/10.2190/2Y7C-KRDV-5U01-UJGA

Bingham-Brown, A. (2012). Non-traditional preservice teachers and their mathematics efficacy beliefs. School Science and Mathematics, 112(3), 191-198. http://dx.doi.org/10.1111/j.1949-8594.2011.00132.x

Blakey, E. \& Spence, S. (1990). Developing metacognition. Syracuse, NY: ERIC Clearinghouse on Information Resources. (Eric Document Reproduction Service No. ED327218).

Butler, D., \& Winne, P. (1995). Feedback and self-regulated learning: A theoretical synthesis. Review of Educational Research, 65, 245-281. http://dx.doi.org/10.3102/00346543065003245

Buyukozturk, S. (2010). Sosyal bilimler için veri analizi el kitabı. Ankara, Turkey: Pegem.

Cardelle-Elawar, M. (1992). Effects of teaching metacognitive skills to students with low mathematics ability. Teaching and Teacher Education, 8, 109-121. http://dx.doi.org/10.1016/0742-051X(92)90002-K

Carter, G., \& Norwood K. S. (1997). The relationship between teacher and student beliefs about mathematics. School Scienee and Mathematics, 97(2), 62-67. http://dx.doi.org/10.1111/j.1949-8594.1997.tb17344.x

Cross, D. R., \& Paris, S. G. (1988). Developmental and instructional analyses of children's metacognition and reading comprehension. Journal of Educational Psychology, 80(2), 131-142. http://dx.doi.org/10.1037/0022-0663.80.2.131

Ekiz, D., \& Yigit, N. (2007). An investigation of student teachers' views of the teacher education models from the angle of different teacher education programs and genders. Journal of Turkish Educational Sciences (TürkEğitimBilimleriDergisi), 5(3), 543-557.

Everson, H. T., \& Tobias, S. (1998). The ability to estimate knowledge and performance in college: A metacognitive analysis. Instructional Science, 26(1-2): 65-79. http://dx.doi.org/10.1023/A:1003040130125

Guven, M., \& Belet, S. D. (2010). Primary school teacher trainees' opinions on epistemological beliefs and metacognition. Primary Education Online, 9(1), 361-378.

Hart, L. C. (2002). Prospective teachers' beliefs and practice after participating in an integrated content/methods course. School Science and Mathematics, 102(1), 4-11. 
Jacobs, J. E., \& Paris, S. G. (1987). Children's metacognition about reading: issues in definition, measurement, and instruction. Educational Psychologist, 22, 255-278. http://dx.doi.org/10.1080/00461520.1987.9653052

Kloosterman, P. (1991). Beliefs and achievement in seventh grade mathematics. Focus on Learning Problems in Mathematics, 13(3), 3-15.

Kloosterman, P., \& Cougan, M. C. (1994). Students' beliefs about learning school mathematics. Primary School Journal, 94(4), 375-388. http://dx.doi.org/10.1086/461773

Kloosterman, P., \& Stage, F. K. (1992). Measuring beliefs about mathematical problem solving. School Science and Mathematics, 92, 109-115. http://dx.doi.org/10.1111/j.1949-8594.1992.tb12154.x

Kuiper, R. (2002). Enhancing metacognition thought: The reflective use of self-regulated learning strategies. The Journal of Continuing Education in Nursing, 33(2), 78-87.

Lin, X. (2001). Designing metacognitive activities. Educational Technology Research and Development, 49(2), 23-40. http://dx.doi.org/10.1007/BF02504926

Livingston, J. A. (1997). Metacognition: An overview. Retrieved October 21, 2008 http://www.gse.buffalo.edu/fas/shull/CEP564/Metacog.htm

Lucangeli, D., \& Cornoldi, C. (1997). Mathematics and metacognition: What is the nature of the relationship? Mathematical Cognition, 3(2), 121-139. http://dx.doi.org/10.1080/135467997387443

Marshall, M. (2003). Metacognition thinking about thinking is essential for learning. Teachers.Net Gazzette, 4(3).

McLeod, D. B. (1992). Research on affect in mathematics education: A reconceptualization. In D. A. Grouws (Ed.), Handbook of research on mathematics teaching and learning (pp.575-596). New York, NY: MacMillan.

Metallidou, P. (2009). Preservice and in-service teachers' metacognitive knowledge about problem solving strategies. Teaching and Teacher Education, 25(1), 76-82. http://dx.doi.org/10.1016/j.tate.2008.07.002

Ministry of Education (2008). Primary mathematics course curriculum book for 6-8 grades (Illkogretim matematik dersi 6-8. siniflar ogretim programi kitabi). Ankara, Turkey: MEB.

National Council of Teachers of Mathematics (2000). Curriculum and evaluation standards. Reston, VA: Author.

Nietfeld, J. L., Cao, L., \& Osborbe, J. W. (2005). Metacognitive monitoring accuracy and student performance in the postsecondary classroom. The Journal of Experimental Education, 74(1), 7-28.

Okcuoglu, V., \& Kahyaoglu, M. (2007). İlköğretim öğretmenlerinin bilişötesi öğrenme stratejilerinin belirlenmesi. Süleyman Demirel Üniversitesi Sosyal Bilimler Enstitüsü Dergisi, 2(6), 129-146.

Ozsoy, G., \& Gunindi, Y. (2011). Preservice preschool teachers' metacognitive awareness. Primary Education Online, 10(2), 430-440.

Philipp, R. A., Ambrose, R., Lamb, L. L. C., Sowder, J. T., Schappelle, B. P., Sowder, L., Thanheiser, E., \& Chauvot, J. (2007). Effects of early field experiences on the mathematical knowledge and beliefs of prospective elementary school teachers: An experimental study. Journal for Research in Mathematics Education, 38(5), 438-476.

Pintrich, P. R. (2002). The role of metacognitive knowledge in learning, teaching, and assessing. Theory into Practice, 41(4), 219-225. http://dx.doi.org/10.1207/s15430421tip4104_3

Raymond, A. M. (1997). Inconsistency between a beginning primary school teacher's mathematics beliefs and teaching practices. Journal for Research in Mathematics Education, 28(6), 552-575.

Schoenfeld, A. H. (1989). Explorations of students' mathematical beliefs and behaviour. Journal for Research in Mathematics Education, 20(4), 338-355. http://dx.doi.org/10.2307/749440

Schraw, G., \& Graham, T. (1997). Helping gifted students develop metacognitive awareness. Roeper Review, 20, 4-8. http://dx.doi.org/10.1080/02783199709553842

Schraw, G., \& Moshman, D. (1995). Metacognitive theories. Educational Psychology Review, 7, 351-371. http://dx.doi.org/10.1007/BF02212307

Schraw, G., \& Sperling-Dennison, R. (1994). Assessing metacognitive awareness. Contemporary Educational Psychology, 19, 460-470. http://dx.doi.org/10.1006/ceps.1994.1033

Schraw, G., Crippen, K. J., \& Hartley, K. (2006). Promoting self-regulation in science education: Metacognition as part of a broader perspective on learning. Research in Science Education, 36, 111-136. http://dx.doi.org/10.1007/s11165-005-3917-8 
Sezgin-Memnun, D., \& Hart, L. C. (2012). Elementary school mathematics teacher trainees' metacognitive awareness levels: Turkey case. Journal of International Education Research, 8(2), 173-182.

Sperling, R. A., Howard, B. C., Staley, R., \& DuBois, N. (2004). Metacognition and self-regulated learning constructs. Educational Research and Evaluation, 10(2), 117-139. http://dx.doi.org/10.1076/edre.10.2.117.27905

Swanson, H. L. (1990). Influence of metacognitive knowledge and aptitude on problem solving. Journal of Educational Psychology, 82(2), 306-314. http://dx.doi.org/10.1037/0022-0663.82.2.306

Swars, S., Hart, L. C., Smith S. Z., Smith, M. E., \& Tolar, T. (2007). A longitudinal study of primary preservice teachers' mathematics beliefs and content knowledge. School Science and Mathematics, 107(8), 325-335. http://dx.doi.org/10.1111/j.1949-8594.2007.tb17797.x

Szydlik, J. E., Szydlik, S. D., \& Benson, S. R. (2003). Exploring changes in preservice primary teachers' mathematical beliefs. Journal of Mathematics Teacher Education, 6(3), 253-279. http://dx.doi.org/10.1023/A:1025155328511

Taskin-Can, B., Canturk-Gunhan, B., \& Ongel-Erdal, S. (2005). Fen bilgisi ogretmen adaylarinin fen derslerinde matematigin kullanimina yonelik oz yeterlik inanclarinin incelenmesi (Examination of self-efficacy beliefs towards using mathematics in science lessons of prospective teachers). Journal of Pamukkale University Education Faculty, $17,47-52$.

Thomas, G. P., \& McRobbie, C. J. (2001). Using a metaphor for learning to improve students' metacognition in the chemistry classroom. Journal of Research in Science Teaching, 38, 222-259. http://dx.doi.org/10.1002/1098-2736(200102)38:2<222::AID-TEA1004>3.0.CO;2-S

Thompson, A. G. (1984). The relationship of teachers' conceptions of mathematics and mathematics teaching to instructional practice. Educational Studies in Mathematics, 15, 105-127. http://dx.doi.org/10.1007/BF00305892

Wilkins, J. L. M., \& Brand, B. R. (2004). Change in preservice teachers' beliefs: An evaluation of a mathematics methods course. School Science and Mathematics, 104(5), 226-232. http://dx.doi.org/10.1111/j.1949-8594.2004.tb18245.x

Yavuz, D., \& Memis, A. (2010). Investigation of self-efficacy perception and metacognitive awareness of preservice teachers. The International Journal of Research in Teacher Education, 1(1), 12-27.

Zimmerman, B. J. (1989). A social cognitive view of self-regulated academic learning. Journal of Educational Psychology, 81(3), 329-339. http://dx.doi.org/10.1037/0022-0663.81.3.329

Zimmerman, B. J., \& Paulsen, A. S. (1995). Self-monitoring during collegiate studying: an invaluable tool for academic self-regulation. In P. R. Pintrich (Ed.), Understanding Self Regulated Learning: New Directions in College Teaching and Learning Number 63 (pp. 13-27). San Francisco: Jossey-Bass. http://dx.doi.org/10.1002/t1.37219956305

Zollman, A., \& Mason, E. (1992). The standards' beliefs instrument (SBI): Teachers' beliefs about the NCTM standards. School Science and Mathematics, 92(7), 359-364. http://dx.doi.org/10.1111/j.1949-8594.1992.tb15609.x

This work is licensed under a Creative Commons Attribution 3.0 License. 